\title{
Impact of Dividend on Share Pricing in Commercial Banks of Nepal
}

\author{
Amar Dhungel
}

ACCA, MBS

CSC and Co. Chartered Accountants

Email: amardhungel11@gmail.com

\begin{abstract}
Dividend is the distribution of a portion of a company's earnings, decided by its board of directors, to a class of its shareholders. Dividend payments are usually the part of a company's strategic policy to return a portion of its profits to its shareholders. Investors in underdeveloped countries like Nepal mostly look at the profitability of the firm while purchasing equity shares from the secondary market. Since dividend paid to the shareholders is one of the best indicators of profitability, it is generally believed that dividend plays a crucial role in determining market price of the corporate share. The relationship between dividend and share price is not yet clear in the literature of finance and it is still a controversial issue in underdeveloped countries like Nepal. This research attempts to analyze the impact of dividend on the stock price movement of Nepalese banks and financial institutions. For that the research basically focuses on secondary data obtained from websites and published material of selected five commercial banks to examine the relationship of Market Price per Share (MPPS) with other financial indicators such as Earnings per Share (EPS), Dividend per Share (DPS) and DPS BS $_{\text {(including }}$ bonus share). Primary data were also obtained from the individuals who own equity shares using a self designed questionnaire. The questionnaires were distributed to 100 shareholders and staff of the banks. The questionnaire focused on the behavior of the investors while purchasing the equity shares in the secondary market. Only 40 samples responded to the call for survey and send back the questionnaire after filling it. Data were analyzed using SPSS software. The findings from this study indicate that there is no significant impact of dividend on share pricing in most of the banks. There is significant correlation between MPPS and EPS as well as MPPS and $\mathrm{DPS}_{\mathrm{BS}}$ in case of only one commercial bank but there was no significant correlation among these variables in other four banks. However positive but insignificant correlation was seen in most of the cases. The results could not be generalized at this moment due to small sample size and there is a need for extensive research on this issue in Nepal.
\end{abstract}

KEYWORDS: Dividend, MPPS, EPS, DPS, DPS ${ }_{B S}$, Equity Share Price

\section{INTRODUCTION AND BACKGROUND OF THE STUDY}

Dividend is defined as that portion of the net earnings of the firm, which is distributed to the shareholders either in the form of cash or stock, as per its dividend policy. Dividend payments are usually part of the company's strategic policy to return a portion of its profits to its shareholders. The dividend ratio provides information about the financial strength and maturity of the company 
along with reflections about its investor's expectations. The dividend can be distributed either in cash or by capitalization of profits as bonus shares.

Investors in underdeveloped countries like Nepal mostly look at the profitability of the firm while purchasing equity shares from the secondary market. Since dividend paid to the shareholders is one of the best indicators of profitability, it is generally believed that dividend plays a crucial role in determining market price of the corporate share (Khadka, 2012). A firm generally pays stock dividend if it plans to increase the capital so as to expand the business. The objective of dividend policy should be to maximize the shareholders return so that the value of their investment is maximized. Dividend decision is one of the major decisions taken by the firm. The amount of dividend declared by a firm is one of the factors that show the actual position of the earnings of the firm. The firm issues equity shares to raise ownership capital and the investors buy them with the ultimate expectation to receive a share of profit. The value of the firm is said to be high when the market price of the company's common stock is higher.

Firms that perform better than others have higher stock prices and can raise additional funds (both debt and equity) in more favorable terms. Therefore, it is important to identify the factors that determine the market price of equity shares of any organization. Financial institutions, including commercial banks in Nepal, are the institutions that mobilize monetary resources in the society. During 1990's along with the economic liberalization in Nepal many joint venture banks were established in the private sector, which mandatorily subscribed shares widely to the general public. Commercial banks appeared as the most profitable business and therefore in the beginning the price of shares of commercial banks continuously went up. However, the stock market had been much volatile in Nepal during the last decade because of internal conflict, political instability, poor corporate governance, and various other reasons.

It is said that when the firm needs to retain a high \%age of earning, they issue stock dividends so that the shareholders of the firms remain content. Managers strongly agree that stock dividends have a positive psychological impact on investors receiving them (Baker and Phillips, 1992). By issuing dividends, management is forced to go to the capital market for additional financing. Higher dividends can directly benefit shareholders because they reduce the free resources which managers can use sub-optimally. Some economists believe that management decides to pay dividends in order to reduce agency costs (Easterbrook, 1984). Each time it attempts to raise fresh capital, its operations are intensely scrutinized by investment bankers, accountants, and other market professionals because these parties have a comparative advantages over the bondholders in monitoring the firm's activities. Dividend payments accompanied by subsequent new financing may lower monitoring costs and thereby increase firm's value (Rao, 1992).

There are reasons for the efficacy of dividends as signals. Dividend announcements are backed by hard-core cash, as it has to be deposited to the shareholders account. The firm must generate this cash internally or convince the capital markets to supply it. In addition, dividend decisions tend to be future oriented as opposed to 
accounting statements which document past performance (Asquith and David, 1986). Besides credibility, dividends also have the advantages of simplicity and visibility. Many others announcements are, at the same time, complex and detailed in focus.

Dividends serve as a simple, comprehensive signal of management's interpretation of the firm's recent performance and its future prospects. The relationship between dividend payout ratio and share price is ambiguous and a topic of debate among the financial laureates throughout the history. The sensitivity of the issue has gained further attention in the underdeveloped countries with full fledged school of thought yet to get any distinct recognition among the various stakeholders. In the milieu of confusions and conflicts there are very few researches done on this regard in Nepal. Hence, this research is an attempt to take the relationship in the spotlight carried out with following objectives.

\section{Objectives of the study}

The main objective of the study is to examine the effect of dividend on pricing system of the equity shares. Following are the specific objectives of the study:

- To examine the relationship between MPPS with other financial indicators such as EPS and Dividend Payout Ratio (DPR);

- To explore the impact of DPS in equity share price behavior;

- To conduct an empirical analysis on shareholders opinion regarding their buying and selling behaviors (of shares).

\section{Related Literature}

The wealth maximization principle also implies that fundamental objective of the firm should be to maximize the market price of the company's share. Firms that perform better than others have higher stock prices and can raise additional funds (both debt and equity) in more favorable terms. Therefore, it is important to identify the factors that determine the market price of equity shares of any organization. Financial institutions, including the commercial banks, in Nepal are the institutions that mobilize monetary resources in the society. Their survival and growth is very important for the growth and development of the nation. Thus, the study of the historical growth of capital market and the equity price behavior of commercial banks in Nepal is much relevant in the present context. The history of capital market in Nepal is not very long. Biratnagar Jute Mills Ltd. was the first company to issue share to general public in 1937. Institutional development of securities market in Nepal started when Securities Exchange Centre (SEC) was established under the Companies Act in 1976. It was established with the joint capital contribution of Nepal Rastra Bank and Nepal Industrial Development Corporation. The objective of the establishment of SEC is to facilitate and promote the growth of capital market in Nepal. It was converted into Nepal Stock Exchange (NEPSE) in 1993, with the establishment of Securities Board. It is a non-profit making organization operating under Securities Exchange Act, 1983. During 1990's along with the economic liberalization in Nepal many joint venture banks established in the private sector, which subscribed shares widely to the general public. Commercial banking has emerged as the safest bet for the most profitable business resulting the ballooning of the share prices even at its infantry and on its 
subsequent stages. Nevertheless, the stock market has been vulnerable recipient of the chaos and turbulences resulting from political instability, conflict, poor corporate governance, attributing the volatility of stock market during the last decade.

Dividend policy has been an issue of interest in financial literature since joint stock companies came into existence. Dividends are commonly defined as the distribution of earnings (past or present) in real assets among the shareholders of the firm in proportion to their ownership (Kapoor, 2009). Dividends and retained earnings significantly explain the variations in share price in both banking and nonbanking sectors (Joshi, 2012). Banks depend on certain financial indicators while making decisions on dividend policy. Dividend on share is an important indicator that shows the performance of banks and thereby attracting the investors. Investors examine the dividend policy of the banks before they decide to invest on stock market but due to fluctuation on dividend policy of commercial banks of Nepal, investors are unable to predict the future earnings from cash dividend (Bhandari and Pokharel, 2012). Regularity of dividend declaration was also viewed as a major element that affect the value of shares, as shareholders believe that regular dividend declaration results in increase in share price. Based on the results, dividend payout, dividend growth rate, and regularity of dividend declaration significantly influenced the market value of National Bank of Kenya shares (Mokaya et al., 2013). A firm dividend policy is influenced by a number of factors like: legal provision, firm liquidity position, need to pay debt, expected rate of return, stability of earning, personal tax, etc (Poudel et al., 2007). The three possible hypotheses with respect to what an investor pays for when he acquires a share of common stock are that s/he is buying (i) both the dividends and the earnings; (2) the dividends only; and (3) the earnings only (Jordon, 2009). Variables dividend, price earnings ratio, and leverage, are significant determinants of share prices for all the sectors under consideration viz. auto, healthcare, and public sector. Further, profitability is found to influence share prices only in the case of auto sector (Nirmala et al., 2011). In a study done in 2004 in Nigeria, no correlation was seen between dividend payment and share prices of Nigerian firms. There was also no correlation between net earnings and share prices. However, the author argued that such result may have occurred due to none availability of items, which are not disclosed in the annual reports of the companies but that are needed for adjustment in computing share prices when computing the earnings (Adefila et. al, 2004). Pradhan (2003) attempted to explain the effect of dividend payment and retained earnings on market price of share in the context of Nepalese companies. The results indicated the customary strong dividend and weak retained earnings effect on market price of share. Dividends were found relatively more attractive among the Nepalese shareholders. It could be inferred from the above discussions that the dividend payouts by the various firms have positive and considerable impact and affect on the value of firms (Aggarwal et al., 2011). Foong et al. (2007) examined dividend related factors that could be relied upon when determining the value of the firm. The results indicated that growth firms had significantly lower dividend yields than non-growth firms. It indicated that changes in dividend policy played a role in explaining firm stock returns especially of the growth firms. 
Khan (2011) reported that stock dividend, Profit after Tax (PAT), EPS, and Return on Equity (ROE) have positive effect on stock prices. Retention ratio has negative effect on stock prices. Overall results of study indicate that dividend policy has significant positive effect on stock prices.

\section{METHODOLOGY}

This research is an exploratory and analytical type in nature and attempts to analyze the impact of dividend on the stock price behavior of financial institution and commercial banks. For that the research basically focuses on secondary data obtained from websites and published material of selected five commercial banks to examine the relationship of MPPS with other financial indicators such as EPS, DPS, and $\mathrm{DPS}_{\mathrm{BS}}$. The five commercial banks were selected by random sampling method from the list of member banks of Nepal Bankers Association (NBA, 2013). Among the listed commercial banks the following five banks viz. Nabil Bank Limited (NABIL), Himalayan Bank Limited (HBL), Nepal Investment Bank Limited (NIBL), Everest Bank Limited (EBL), and Lumbini Bank Limited (LUMBINI) were selected for the study and secondary data were received from their respective websites. The secondary data were from the fiscal year (FY) 2004/05 to 2010/11.

Primary data were also obtained using a self-designed questionnaire from the individuals who own equity shares. The questionnaires were distributed to 100 shareholders and staff of the banks. The convenience sampling was used to collect primary data. The questionnaire focused on the behavior of the investors while purchasing the equity shares in the secondary market. The questionnaire also examines whether the investor analyses financial health of the institution and the overall market and several other aspects that a good investor is supposed to look at. Only 40 samples responded ad send back the questionnaires after filling it. Data were analyzed using SPSS software and presented in this paper.

\section{RESULT AND DISCUSSION}

\section{Empirical Study: Response of Individuals}

The detail of the respondents is shown in the table (Table 1). It categorizes the respondents by their sex and age. Around four-fifth of the respondents were found to be male. Again, about $80 \%$ of the respondents turn out to be holding the shares of more than one company. It shows that the investor, who is aware of opportunity in investing in equity shares, goes on searching for the prospect to invest more and more in the shares. The table shows that the numbers of respondents who invest in multiple financial institutions are relatively higher. 
Table 1: Composition of Respondents

\begin{tabular}{llrr}
\hline Descriptions & Category & Number & \%age \\
\hline Sex & Male Respondents & 32 & 80.00 \\
\multirow{4}{*}{ Age } & Female Respondent & 8 & 20.00 \\
& Age 16 to 24 & 6 & 15.00 \\
\multirow{4}{*}{ Share owning pattern } & Age 25 to 50 & 25 & 62.50 \\
& Age > 50 & 9 & 22.50 \\
& In only one financial institutions & 8 & 20.00 \\
& In multiple Financial Institution & 32 & 80.00 \\
\hline
\end{tabular}

The responses given by the samples are presented in the figures (Figure 1-7).

Figure (1) depicts the respondent's reason for investing in equity shares in secondary market. Most of the responses were in favor of prospects of higher share price in future. This shows that these people were looking for capital gains from equity shares. Such response counted at $47 \%$ of the total responses. Furthermore, $7.5 \%$ of the respondents quoted prevailing market price of the equity shares as major reason for purchasing equity shares. Out of total respondents, $15 \%$ of the respondent said that they purchased shares due to lack of alternative investment in the country and the remaining $30 \%$ said that they purchased shares with a hope that they can gain benefits from the banks in the form of bonus shares, right shares, and cash dividends.

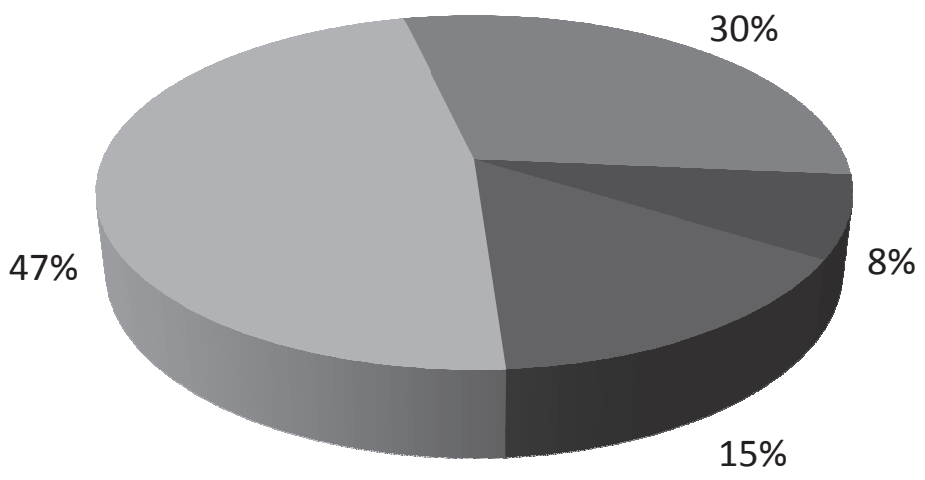

Lack of alternative investment

Prospects of higher share price in future

Future benefits from the institutions

Prevailing share prices

Figure 1: Inspiration of investment in equity shares in secondary market

Regarding awareness of the companies they invest, of the total respondents, $87.5 \%$ said that they were aware of the financial health of the company while making the investment. However, $12.5 \%$ of them were not aware of financial health (Figure 2). 


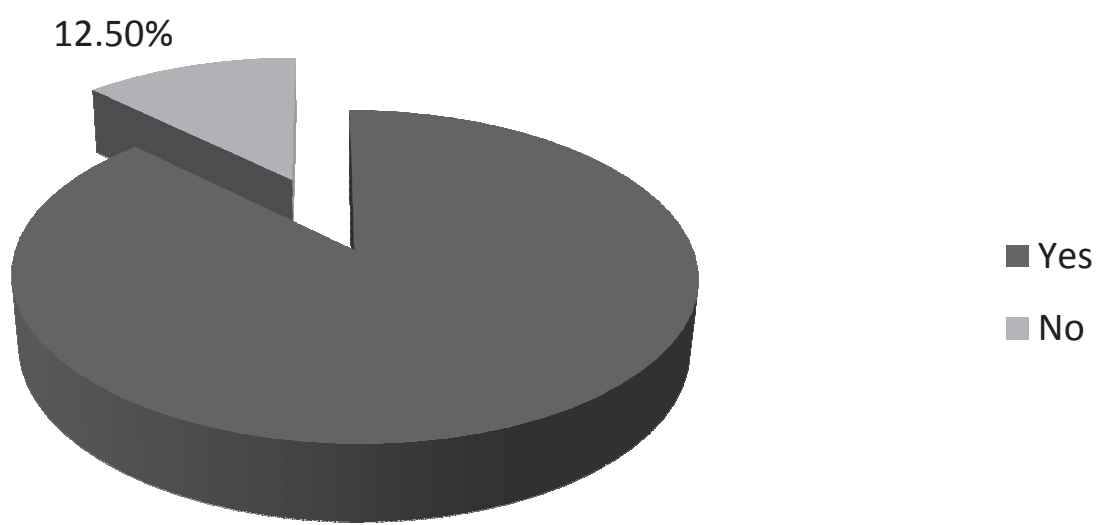

$87.50 \%$

Figure 2: Awareness of the financial health of the institution

On response to the question on factors looked for amongst various financial indicators while purchasing the equity shares in the secondary market, $40 \%$ of the respondents quoted the profitability behind their motive to buy equity share in the secondary market and $27.5 \%$ of the respondents said they are interested in dividends (Figure 3). They expressed their hope verbally that the bank would offer bonus shares in the future. All those who said they look at net worth per share, dividend payout ratio, and other factors such as management and future growth while seeing financial health of the bank said that each of these factors were also the motives for the purchase of the equity shares.

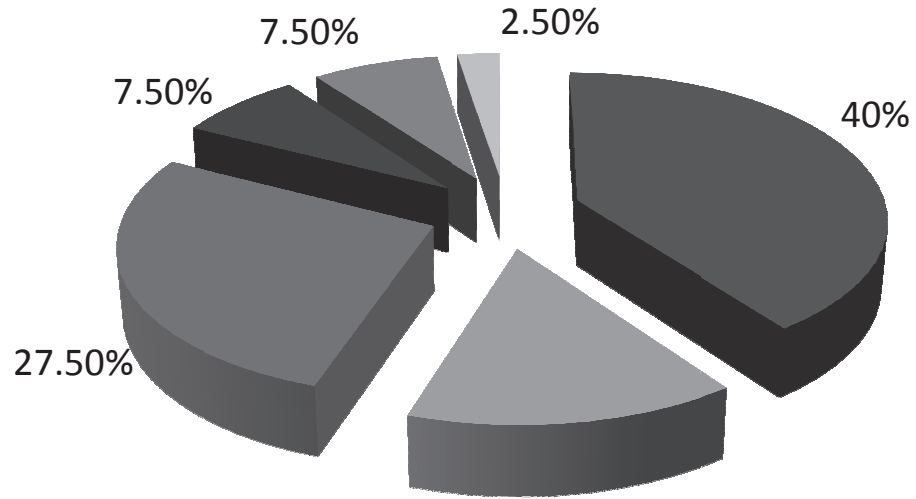

$15 \%$
- Profitability

Earning per share

- Dividend per share

net worth per share

Dividend payout Ratio

Others

Figure 3: Factors looked for amongst various financial indicators while purchasing the equity shares in the secondary market

Amongst those who said they do not care for financial health while purchasing equity shares in the secondary market, there was one supporting question which read as: If you were not aware of the financial health of the institution, why did you 
invest in the equity shares in Secondary Markets? [Respond if your answer to Q2 is No].

Out of the 5 respondents, who said that they do not care to the financial health of the companies they are investing in, said that the market price of the bank $(40 \%)$ and influence from the family (40\%) were factors that made them invest in the equity shares (Figure 4). Remaining 20\% bought shares from the secondary market due to the demonstration effect, that is, their friends and close relatives were purchasing equity shares quite regularly.

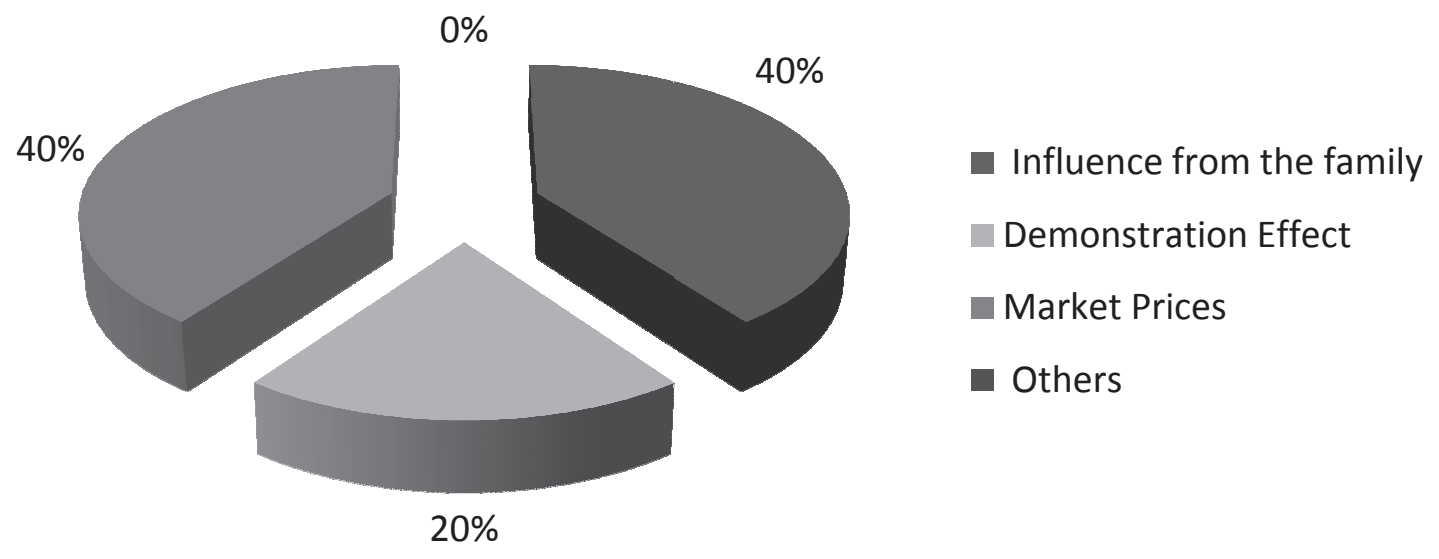

Figure 4: Reasoning for investing in the equity shares in secondary markets (for respondents unaware of financial health of the institution)

The awareness of the investors on all the directives issued by the Nepal Rastra Bank, Securities Board, Nepal Stock Exchange, and other related authorities were also examined. The response showed that $70 \%$ were aware of these things and $30 \%$ were not aware of this information, indicating that these groups of respondents are not bothered with the other financial indicators in the share market. Amongst those who cared for other financial indicators the following are the indicators that they look into. About 33\% of the respondents said they look at the NEPSE index and $37.5 \%$ said that they look for the share market growth (Figure 5).

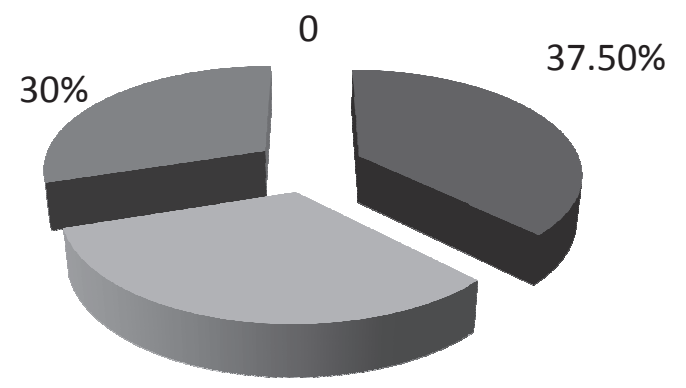

$32.50 \%$
- Share Market growth

NEPSE Index

No

Other

Figure 5: Awareness about other financial indicators 
Figure (6) demonstrates the investor's perception regarding the prices of the equity shares. The question was intended to see if the investors think that the share price that they are paying is just right or not. The response showed that a total of $62.5 \%$ (25 respondents) thought that the share prices were not just right and thus does not correspond to the financial health of the institution. Among these respondents $60 \%$ said that the market price is overvalued, $24 \%$ said that it is undervalued and $16 \%$ said they cannot answer this (not shown in figures).

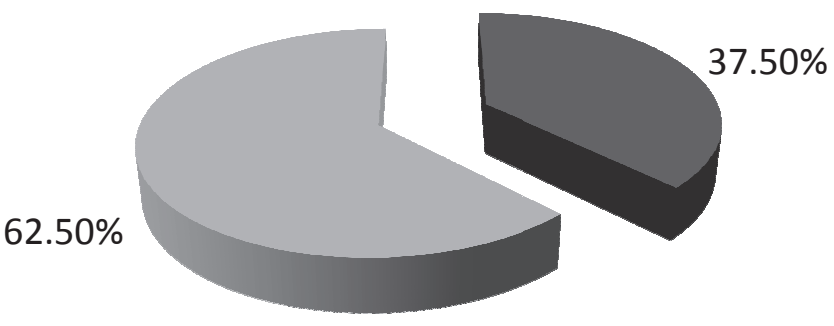

$$
\begin{aligned}
& \text { Yes } \\
& \text { No }
\end{aligned}
$$

Figure 6: Perception regarding the correlation of price with financial health of the institution

Rating of risks in share market by share investors has been presented in the figure *Figure 8). Around $35 \%$ of the respondents were unaware of the risk-factor in the share investment. Their response simply turned out to be "Don't Know". Most of the respondents who said they had some idea on the associated risk responded that the risk factor is higher $(12 \%+30 \%=42 \%)$. Around $15 \%$ of the responses perceived normal and natural risks in the share market too. Only $7 \%$ of the responded said the risk is very low.

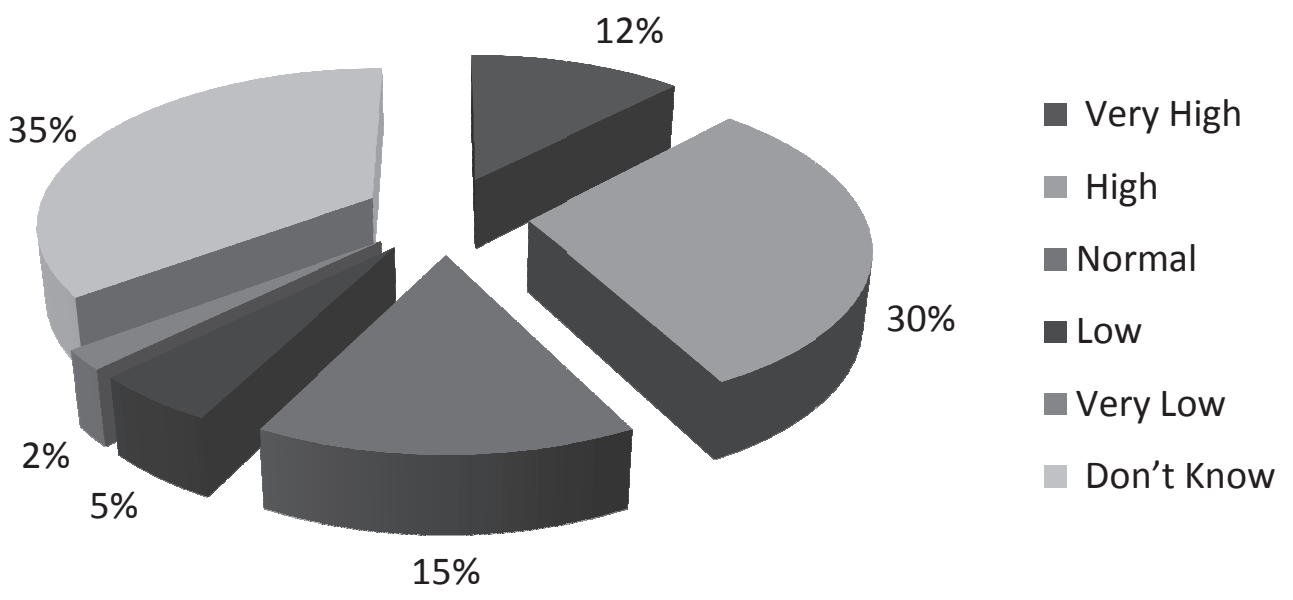

Figure 8: Rating of risk-factors in the share market by share investors 
The tables (Table 2-4) showed the relationship between MPPS and other financial indicators: DPS, DPS ${ }_{\mathrm{BS}}$, and EPS. The correlation coefficient helps to determine whether there exists any relationship among different variables.

The Table (2), it is clear that there is high degree of relationship between MPPS and DPS. There is negative correlation between MPPS and DPS of EBL, NIBL, and LUMBINI. However, the correlation between MPPS and DPS is statistically significant in case of NIBL only. This means that as the MPPS of NIBL increases, there is decrease in the DPS of same.

Table 2: Correlation analysis between MPPS and DPS of the banks

\begin{tabular}{|c|c|c|c|}
\hline S. No. & Name of the Bank & Correlation Coefficient $\mathbf{R}_{\text {DPS }}$ & P(value) \\
\hline 1 & NABIL & $\begin{array}{ll} & 0.63 \\
\end{array}$ & 0.24 \\
\hline 2 & $\mathrm{EBL}$ & -0.77 & 0.12 \\
\hline 3 & $\mathrm{HBL}$ & 0.38 & 0.52 \\
\hline 4 & NIBL & -0.88 & $* 0.04$ \\
\hline 5 & LUMBINI & -0.68 & 0.20 \\
\hline
\end{tabular}

The degree of relationship between MPPS and EPS seems to be highly positive in NABIL and HBL (Table 3), although it is only significant in case of HBL. In NIBL, $\mathrm{EBL}, \mathrm{LBL}$, the correlation coefficient between MPPS and EPS is comparatively lower.

Table 3: Correlation analysis between MPPS and EPS of the banks

\begin{tabular}{|c|c|c|c|}
\hline S.N. & Name of the Bank & Correlation Coefficient ( $\left.\mathbf{R}_{\mathrm{DPS}}\right)$ & P-value \\
\hline 1 & NABIL & 0.93 & 0.20 \\
\hline 2 & EBL & 0.11 & 0.86 \\
\hline 3 & $\mathrm{HBL}$ & 0.88 & $* 0.05$ \\
\hline 4 & NIBL & 0.40 & 0.50 \\
\hline 5 & LUMBINI & 0.65 & 0.23 \\
\hline
\end{tabular}

* Significant $\mathrm{p}<=0.05$

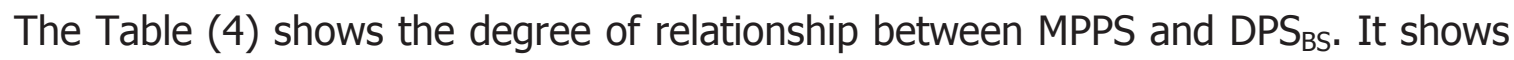
that the relationship is positive and significant in case of $\mathrm{HBL}$ only. The degree of relationship between MPPS and DPS in case of NABIL and EBL is positive but insignificant. But the degree of relationship between MPPS and DPS ${ }_{B S}$ is negative in case of NIBL and LUMBINI (indicated by negative correlation coefficient value).

Table 4: Correlation analysis between MPPS and DPS $_{\mathrm{BS}}$ of the banks

\begin{tabular}{|c|c|c|c|}
\hline S. No. & Name of the Bank & Correlation Coefficient ( $\left.\mathbf{R}_{\mathrm{DPS}}\right)$ & P(value) \\
\hline 1 & NABIL & 0.85 & 0.07 \\
\hline 2 & $\mathrm{EBL}$ & 0.74 & 0.15 \\
\hline 3 & $\mathrm{HBL}$ & 0.91 & * 0.03 \\
\hline 4 & NIBL & -0.05 & 0.93 \\
\hline 5 & LUMBINI & -0.68 & 0.20 \\
\hline
\end{tabular}


From the above analysis, it is clear that the correlation of MPPS and EPS as well as MPPS and DPS ${ }_{B S}$ were positively significant in case of $\mathrm{HBL}$ only, and the correlation of MPPS and DPS is significant in case of NIBL. So, we tried to develop the regression equation of MPPS and EPS as well as MPPS and DPS BS $_{\text {for }}$ HBL and equation of MPPS and DPS for NIBL. The results are presented in the tables (Table 5,6 , and 7), so that MPPS can be predicted from EPS, DPS, and DPS ${ }_{B S}$.

The Table (5) shows the regression equation between MPPS (y) and DPS (x) of the NIBL. Here, DPS is independent variable and MPPS is the dependent variable. With the help of these indicators, we can obtain the slope (b) and the intercept (a) of the equation as: $y=a+b x$. The results showed that the coefficient $(b)$ is negative for NIBL. This result is difficult to explain. The size of the estimated regression coefficient suggests that for every additional increase of DPS, the MPPS decreases by 72.17 , in case of NIBL.

\section{Table 5: Regression Equation of MPPS and DPS}

\begin{tabular}{|c|c|c|c|c|}
\hline \multicolumn{4}{|c|}{ Regression Coefficient } & \multirow[t]{2}{*}{ Equation $(y=a+b x)$} \\
\hline (a) & P-Value & (b) & P- Value & \\
\hline 2548.32 & 0.01 & -72.17 & 0.05 & MPPS $=2548.32-72.17$ DPS \\
\hline
\end{tabular}

Table (6) shows the regression equation between MPPS and EPS of the HBL. It can be seen that regression coefficient (b) is positive in HBL. The size of the estimated regression coefficient suggests that for every additional increase of EPS, the MPPS increases by 40.87 in case of HBL.

\section{Table 6: Regression Equation of MPPS and EPS}

\begin{tabular}{rrrrrr}
\hline \multicolumn{2}{l}{ Regression Coefficient } & & & & Equation (y=a+bx) \\
\hline (a) & P-Value & $\mathbf{( b )}$ & P- Value & \\
\cline { 6 - 6 } \cline { 5 - 6 } & 0.365 .23 & 40.87 & 0.04 & & MPPS $=-765.23+40.87$ EPS \\
\hline
\end{tabular}

The Table (7) shows the regression equation between MPPS and DPS ${ }_{B S}$ of HBL. Here, $D_{P S}$ is independent variable and MPPS is the dependent variable. The results showed that for every additional increase of DPS $_{B S}$, the MPPS increases by 153.45 in case of HBL.

Table 7: Regression Analysis between MPPS and DPS $_{\mathrm{BS}}$ Regression Coefficient

(a) P-Value

(b)

P- Value

$-4832.7$

$0.06 \quad 153.45$

0.03

Equation $(y=a+b x)$

\section{CONCLUSION}

Among the total respondents, $87 \%$ of the share investors care for the financial health of the company before purchasing equity shares from the secondary market. Amongst the financial health all investors care for the profitability of the institution, of which around $75 \%$ of the respondents look for dividend per share. 
The degree of relationship between MPPS and DPS is found to be positive in case of NABIL and HBL, whereas negative for NIBL, EBL, and LUMBINI. However, it is only significant in case of NIBL. This result is somewhat unexplainable. On the other hand, the degree of relationship between MPPS and EPS seems to be highly positive in Nabil Bank but it is insignificant. However, it is significantly positive in case of HBL. The correlation coefficient between MPPS and EPS is insignificant, positive, and moderate for LUMBINI, EBL, and NIBL. The correlation coefficient between MPPS and $D^{2} S_{B S}$ is found to be positive for NABIL, EBL, and $H B L$, however, it is only significant in case of HBL. Similarly, NIBL and LUMBINI have negative signs but these are again not significant.

On the whole, it can be said that although there is mostly positive relationship between MPPS and EPS / DPS ${ }_{B S}$, mostly this is not significant. The worldwide studies conclude a varying influence of dividend policy even in financially and economically high growth and stable countries (Garrett and Priestley, 2000). In countries like Nepal where financial sector is still in infancy and growing slowly, predicting dividend policy of banks is difficult and uncertain. It is also difficult to assume that most of the shareholders / investors decide rationally after looking at different indicators of the company they are investing in. However, the growing financial sector in recent years with the increasing number of financial institutions has increased the scope of examining dividend policy and contributing to recommend policy agenda that can help to improve the financial sectors. Investors are also required to go thoroughly through available data on the companies for their investment to be secure and provide lucrative returns.

There are various other indicators that this research does not consider as well as many factors intrinsic to the individual companies and are not disclosed publicly, making it inaccessible through secondary sources. This may as well influence the MPPS but are not included in this research. Due to small sample size, limited data from limited banks, and limited indicators used in this research, the findings could not be generalized for all Nepalese companies. Also, the relationship between MPPS and DPS is found significantly negative in case of NIBL, which could not be explained. These are some of the shortcomings of this research and needs further explorations. But this is a preliminary research and an initiation in this regard. This research needs to be refined with more research with more data from several companies listed in the NEPSE.

\section{ACKNOWLEDGEMENT}

This research has been partially funded by the Nepal Bankers' Association, Banking Promotion Committee Research Grant, RG\#6(B).

\section{REFERENCES}

Adefila, J. J., J. A. Oladipo, and J. O. Adeoti. 2004. The Effect of Dividend Policy on the Market Price of Shares in Nigeria: Case Study of Fifteen Quoted Companies. International Journal of Accounting, 2 (1): Pp. 82-91.

Aggarwal, D. and J. S. Pasricha. 2011. Relationship between Dividend Policy and Value of Firm - A Study of Information Technology Industry and 
Pharmaceuticals Industry in Indian context. http://www.ccfr.org.cn/cicf201 2/papers/20120104143625.pdf.

Bhandari, B. and T. Pokharel. 2012. Corporate Dividend Policy: A Study of Commercial Banks of Nepal. Journal of Administrative and Management Review, 24 (2): Pp. 24-44.

Foong, S., N. Zakaria, and H. Tan. 2007. Firm Performance and Dividend related factors: The case of Malaysia. Labuan Bulletin of International Business and Finance, 5: Pp. 97-111.

Garrett, I. and R. Priestley. 2000. Dividend Behavior and Dividend Signaling. The Journal of Financial and Quantitative Analysis, 35 (2): Pp. 173-189.

Jordon, M. and J. October. 2009. Dividends, Earnings, and Stock Prices. The Review of Economics and Statistics, 41 (2): Pp. 99-105.

Joshi, R. 2012. Effect of Dividend on Stock Price in Nepal. NRB Economic Review, 24 (2): Pp 61-75.

Kapoor, S. 2009. Impact of Dividend Policy on Shareholders' Value: A Study of Indian Firms. PhD Thesis (Unpublished), Jaypee Business School, Jaypee Institute of Information Technology, Noida, India.

Khadka, K. 2012. Effect of Dividend on Share Pricing in Nepal. Master's Thesis (Unpublished), Shankardev Campus, Tribhuvan University, Kathmandu, Nepal.

Mokaya, S. O., D. M. Nyang'ara, and L. T. James. 2013. The Effect of Dividend Policy on Market Share Value in the Banking Industry: the Case of National Bank of Kenya. International Journal of Arts and Commerce, 2 (2): Pp. 91101

NBA. 2013. Member List. Nepal Bankers' Association Website. http://nepalbankers .com.

Nirmala, P. S., P. S. Sanju, and M. Ramachandran. 2011. Determinants of Share Prices in India. Journal of Emerging Trends in Economics and Management Sciences, 2 (2): Pp 124-130.

Poudel, R B., K. J. Baral, R. R. Gautam, G. B. Dahal, and S. B. Rana. 2007 (2064). Fundamentals of Financial Management. Asmita Publication, Kathmandu, Nepal (Pp. 490-514).

Pradhan, R. S. 2003. Effects of Dividends on Common Stock Prices: The Nepalese Evidence. Working Paper Series, Research in Nepalese Finance, Buddha Academics, Kathmandu, Nepal. 


\section{ANNEXES}

\section{Annex 1: Questionnaire}

1. What inspired you to invest in the equity shares in the secondary market?
a) Lack of alternative investment
b) Prospects of higher prices in future
c) Future benefits from the institution
d) Prevailing Prices

2. While investing, were you aware of the financial health of the institution?
a) Yes
b) No

3. What factor amongst the financial health inspired you to purchase the equity shares in the secondary market?
a) Profitability
b) Earnings per Share
c) Dividend per Share
d) Net Worth per Share
e) Dividend Payout Ratio
f) Others (specify):

4. If you were not aware of the financial health of the institution, why did you invest in the equity shares in secondary markets?

[Respond if yours answer to $q_{2}$ is no]
a) Influence from the family
b) Purchase of shares in the close circles
c) Market Prices
d) Others (specify):

5. Were you aware of financial indicators such as NEPSE index, share market growth, and others? What?
a) Yes
b) NEPSE Index
c) Others:
d) No

6. What do you think regarding the prices of the equity shares? (This question was intended to see if the investors think that the share price that they are paying is just right or not?)
a) Yes
b) No

7. Do you think the price that you pay correspond the financial health of the institution? [Respond if your answer to $Q .2$ is yes].
a) Yes
b) No

8. How do you rate the risk-factor in the share market?
a) Very High
b) High
c) Normal
d) Low
e) Very Low
f) Don't Know 
Annex 2: Earning Per Share of the Banks

\begin{tabular}{|l|r|r|r|r|r|}
\hline Fiscal Year & NABIL & EBL & HBL & LUMBINI & NIBL \\
\hline $2006 / 07$ & 137.00 & 78.42 & 60.66 & 32.07 & 62.57 \\
\hline $2007 / 08$ & 115.86 & 91.82 & 62.74 & 32.91 & 57.87 \\
\hline $2008 / 09$ & 113.44 & 99.99 & 61.90 & 30.31 & 37.42 \\
\hline $2009 / 10$ & 83.81 & 100.16 & 31.80 & 23.49 & 52.55 \\
\hline $2010 / 11$ & 70.67 & 83.18 & 44.66 & 29.98 & 48.84 \\
\hline Mean & $\mathbf{1 0 4 . 1 6}$ & $\mathbf{9 0 . 7 1}$ & $\mathbf{5 2 . 3 5}$ & $\mathbf{2 9 . 7 5}$ & $\mathbf{5 1 . 8 5}$ \\
\hline SD & 26.63 & 9.80 & 13.69 & 3.71 & 9.60 \\
\hline CV & 25.57 & 10.81 & 26.15 & 12.45 & 18.52 \\
\hline
\end{tabular}

Annex 3: Market Price per Share of the Banks

\begin{tabular}{|l|r|r|r|r|r|}
\hline Fiscal Year & NABIL & EBL & HBL & LUMBINI & NIBL \\
\hline $2006 / 07$ & 5050 & 2430 & 1740 & 505 & 1729 \\
\hline $2007 / 08$ & 5275 & 3132 & 1980 & 631 & 2450 \\
\hline $2008 / 09$ & 4899 & 2455 & 1760 & 435 & 1388 \\
\hline $2009 / 10$ & 2384 & 1630 & 816 & 303 & 705 \\
\hline $2010 / 11$ & 1252 & 1094 & 575 & 221 & 515 \\
\hline Mean & $\mathbf{3 7 7 2}$ & $\mathbf{2 1 4 8}$ & $\mathbf{1 3 7 4}$ & $\mathbf{4 1 9}$ & $\mathbf{1 3 5 7}$ \\
\hline SD & 1833 & 794 & 632 & 162 & 786 \\
\hline CV & 49 & 37 & 46 & 39 & 58 \\
\hline
\end{tabular}

Note: Decimals are not included

Annex 4: Dividend per Share of the Banks

\begin{tabular}{|l|r|r|r|r|r|}
\hline Fiscal Year & NABIL & EBL & HBL & LUMBINI & NIBL \\
\hline $2006 / 07$ & 100 & 10 & 15 & 0 & 5 \\
\hline $2007 / 08$ & 60 & 20 & 25 & 0 & 7.5 \\
\hline $2008 / 09$ & 35 & 30 & 12 & 0 & 20 \\
\hline $2009 / 10$ & 30 & 30 & 12 & 0 & 25 \\
\hline $2010 / 11$ & 30 & 50 & 17 & 0.53 & 25 \\
\hline Mean & $\mathbf{5 1}$ & $\mathbf{2 8}$ & $\mathbf{1 6}$ & $\mathbf{0 . 1 1}$ & $\mathbf{1 7}$ \\
\hline SD & 30 & 15 & 5 & 0.24 & 10 \\
\hline CV & 59 & 53 & 33 & 223.61 & 58 \\
\hline
\end{tabular}

Note: Decimals are not included, except for LUMBINI since it has very lower values 
Annex 5: Dividend Payout Ratio of Sampled Banks

\begin{tabular}{|l|r|r|r|r|r|}
\hline Fiscal Year & NABIL & EBL & HBL & LUMBINI & NIBL \\
\hline $2006 / 07$ & 140 & 30 & 40 & 0 & 30 \\
\hline $2007 / 08$ & 100 & 30 & 45 & 0 & 41 \\
\hline $2008 / 09$ & 85 & 30 & 44 & 0 & 20 \\
\hline $2009 / 10$ & 70 & 30 & 37 & 0 & 25 \\
\hline $2010 / 11$ & 30 & 10 & 37 & 10 & 50 \\
\hline Mean & $\mathbf{8 5}$ & $\mathbf{2 6}$ & $\mathbf{4 0}$ & $\mathbf{2}$ & $\mathbf{3 3}$ \\
\hline SD & 40 & 9 & 4 & 4.47 & 12 \\
\hline CV & 47 & 34 & 9 & 223.61 & 37 \\
\hline
\end{tabular}

Note: Decimals are not included, except for LUMBINI since it has very lower values

Annex 6: Regression equation of MPPS and DPS

\begin{tabular}{|l|r|r|r|r|r|}
\hline \multirow{2}{*}{ Bank } & \multicolumn{3}{|c|}{ Regression Coefficient } & \multirow{2}{*}{ Equation $(\mathbf{y = a + b x )}$} \\
\cline { 2 - 5 } & $\mathbf{( a )}$ & P-Value & $\mathbf{( b )}$ & P- Value & \\
\hline NABIL & 1797.00 & 0.33 & 38.73 & 0.25 & MPPS $=1797+38.725$ DPS \\
\hline EBL & 3311.41 & 0.12 & -41.54 & 0.12 & MPPS $=3311.41+41.54$ DPS \\
\hline HBL & 651.35 & 0.58 & 44.79 & 0.53 & MPPS $=651.35+44.79$ DPS \\
\hline NIBL & 2548.32 & 0.01 & -72.17 & 0.05 & MPPS $=2548.32-72.17$ DPS \\
\hline LUMBINI & 468.50 & 0.01 & -466.99 & 0.20 & MPPS $=468.50-466.99$ DPS \\
\hline
\end{tabular}

Annex 7: Regression equation of MPPS and EPS

\begin{tabular}{|l|r|r|r|r|r|}
\hline \multirow{2}{*}{ Bank } & \multicolumn{4}{|c|}{ Regression Coefficient } & \multirow{2}{*}{ Equation (y=a+bx) } \\
\cline { 2 - 5 } & $\mathbf{( a )}$ & P-Value & $\mathbf{( b )}$ & P- Value & \\
\hline NABIL & -2933.43 & 0.15 & 64.38 & 0.00 & MPPS $=-2933.43+64.38 \mathrm{EPS}$ \\
\hline EBL & 1318.00 & 0.78 & 9.15 & 0.86 & MPPS $=1318.00+9.15 \mathrm{EPS}$ \\
\hline HBL & -765.23 & 0.34 & 40.87 & 0.05 & MPPS $=-765.23+40.87 \mathrm{EPS}$ \\
\hline NIBL & -356.96 & 0.89 & 33.06 & 0.50 & MPPS $=-356.96+33.06 \mathrm{EPS}$ \\
\hline LUMBINI & -425.54 & 0.51 & 28.38 & 0.24 & MPPS $=-425.54+28.38 \mathrm{EPS}$ \\
\hline
\end{tabular}

Annex 8: Regression Equation of MPPS and DPS

\begin{tabular}{|l|r|r|r|r|r|}
\hline \multirow{2}{*}{ Bank } & \multicolumn{4}{|c|}{ Regression Coefficient } & \multirow{2}{*}{ Equation (y=a+bx) } \\
\cline { 2 - 5 } & $\mathbf{( a )}$ & P-Value & $\mathbf{( b )}$ & P- Value & \\
\hline NABIL & 473.28 & 0.73 & 38.80 & 0.07 & MPPS $=473.28+38.80$ DPR \\
\hline EBL & 435.12 & 0.67 & 65.89 & 0.15 & MPPS $=435.12+65.89 \mathrm{DPR}$ \\
\hline HBL & -4832.71 & 0.06 & 153.45 & 0.03 & MPPS $=-4832.71+153.45 \mathrm{DPR}$ \\
\hline NIBL & 1427.00 & 0.34 & -3.48 & 0.93 & MPPS $=1427.00+-3.48 \mathrm{DPR}$ \\
\hline LUMBINI & 468.50 & 0.01 & -24.75 & 0.20 & MPPS $=468.50+-24.75 \mathrm{DPR}$ \\
\hline
\end{tabular}

